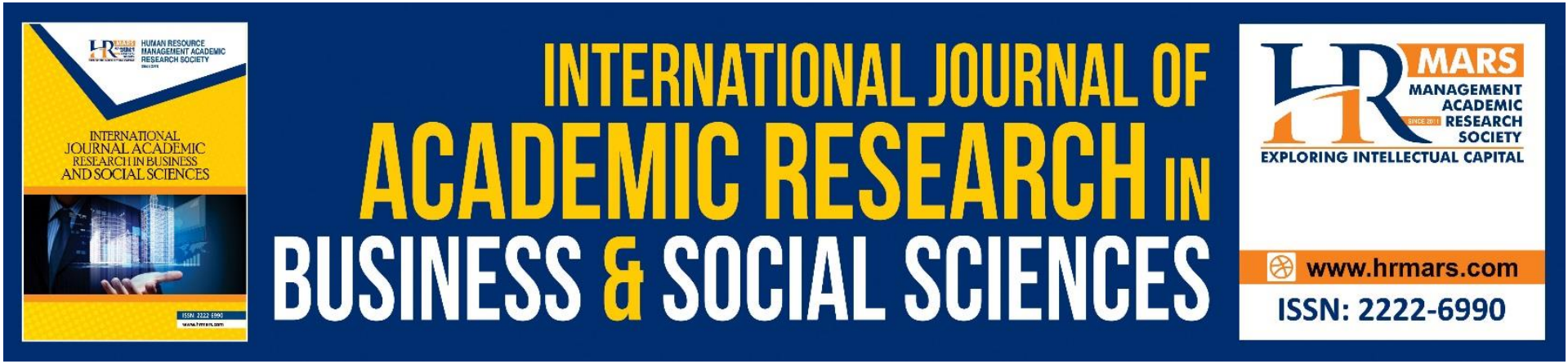

\title{
Conflict Aspects between French and Malay Verbal Systems
}

\section{Hamid Omar \& Omrah Hassan @ Hussin}

To Link this Article: http://dx.doi.org/10.6007/IJARBSS/v11-i1/8307

DOI:10.6007/IJARBSS/v11-i1/8307

Received: 10 November 2020, Revised: 07 December 2020, Accepted: 28 December 2020

Published Online: 15 January 2021

In-Text Citation: (Omar, \& Hussin, 2021)

To Cite this Article: Omar, H., \& Hussin, O. H.@ (2021). Conflict Aspects between French and Malay Verbal Systems. International Journal Academic Research in Business and Social Sciences, 11(1), 388-399.

Copyright: (C) 2021 The Author(s)

Published by Human Resource Management Academic Research Society (www.hrmars.com)

This article is published under the Creative Commons Attribution (CC BY 4.0) license. Anyone may reproduce, distribute, translate and create derivative works of this article (for both commercial and non-commercial purposes), subject to full attribution to the original publication and authors. The full terms of this license may be seen at: http://creativecommons.org/licences/by/4.0/legalcode

Vol. 11, No. 1, 2021, Pg. 388 - 399

http://hrmars.com/index.php/pages/detail/IJARBSS

JOURNAL HOMEPAGE

Full Terms \& Conditions of access and use can be found at http://hrmars.com/index.php/pages/detail/publication-ethics 


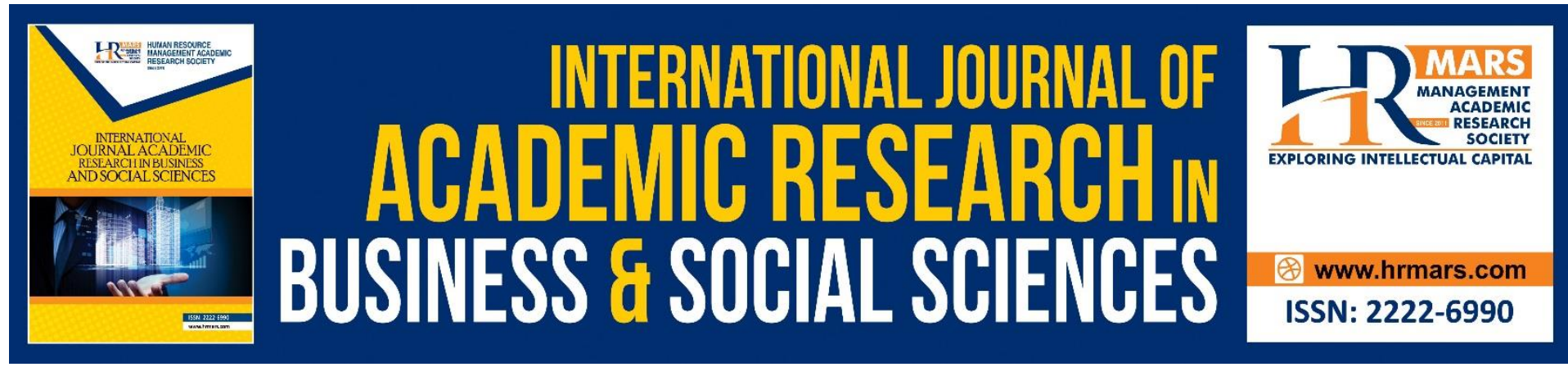

\title{
Conflict Aspects between French and Malay Verbal Systems
}

\author{
Hamid Omar \& Omrah Hassan @ Hussin
}

Department of Foreign Languages, Faculty of Modern Languages and Communication, Universiti Putra Malaysia (UPM), 43400 UPM Serdang, Selangor Darul Ehsan, Malaysia

Email: hameedomar@upm.edu.my,omrah@upm.edu.my

\begin{abstract}
Mother-tongue Interference in the acquisition of the target language is a commonplace for almost all foreign languages' learners. In the case of Malaysian learners of French, it is somewhat different. The interference is occurring between two completely different linguistic systems, especially with regard to verbal systems. While the French verb informs us through its root and its infinitive form about the action to perform, and through its conjugated forms about the person, the number of persons performing the action, about the aspect and the tense of the action, the Malay verb, lacks all other information except the action to perform. These differences lead Malaysian learners of French to confuse between infinitive and conjugated verbs, between verb tenses and between conjugated verb endings, etc. In other words, it concerns the unconscious large interference between Malay and French languages that affects the structure and the meaning in French and, consequently, confuses the listener or the reader and causes communication to fail. The current study will focus on the conflict between French and Malay verbal systems. It does not agree with the approach of Representational Deficit Hypothesis and aims to promote a way based on the transformation of the explicit knowledge of French verbal grammar to implicit or almost implicit knowledge in order to avoid such conflict.
\end{abstract}

Keywords: Languages Interference, French Verb, Malay Verb, Explicit Knowledge, Implicit Knowledge.

\section{Introduction}

Whoever had the opportunity to teach French to Malay native speakers would quickly discover that they have great ease in reading and in pronouncing nasal syllables, while they have great difficulties with verb conjugation and verb-grammar. This could be attributed to various reasons, but the languages interference is likely the most important one.

We intend by languages interference the influence of the learners' first language (L1) or mother tongue on their production of the foreign language they are learning (L2). This interference may affect one or several aspects of language: pronunciation, syntax, morphology, semantics, and so on. This interference could play a positive role and facilitate the learning of linguistic aspects similar in both languages. Conversely, with greater differences between the two languages, more negative effects of interference are expected 
(Munkhtsetseg, 2017). Although, when dealing with interference between languages, two things are very important to keep in mind. Firstly, all languages are different and don't perform in the same way. Secondly, it goes without saying that all foreign language learners around the world may find difficult to use a suitable expression when they want to express themselves in speaking or in writing in the language they are learning, so they resort to the trick of using a direct translation of their mother language (Krashen, 1981). For example, an Arabic speaker might say "it is not important for me" instead of "I don't mind", "from last year" instead of "since last year".

In the case of Malaysian learners of French, it is a bit different. The interference is occurring between two completely different linguistic systems, especially with regard to verbal systems. In other words, it concerns the unconscious large interference between Malay and French languages that affects the structure and the meaning in French. Wrongly using an infinitive form or incorrect conjugated form in French will definitely result in confusing the listener or the reader and cause communication to fail. Furthermore, Malaysian learners of French who are aware of the gap between the two verbal systems in French and in Malay, seem to overcomplicate the matter through the constant use of mental translation of their thought in their mother tongue.

Thus the high percentage and types of errors made by Malaysian learners of French lead us to consider whether the number of transformations required by the use of French verbs is beyond the abilities and understanding of Malaysian learners, as was argued in the approach of Representational Deficit Hypothesis (Hawkins and Chan, 1997; Hawkins, 2000, 2003). Here it has been argued that foreign language learners are unable to accurately understand or produce the morphosyntactic features not present in their mother languages, and compensate that deficit by systematically using the grammar of L1 to form such structures in L2. Rather it is a matter of time and punctual teaching and learning. This study aims to answer to these questions.

\section{Data and Context of the Study}

In my first lecture with Malaysian students in their third year of university, I asked them to write down two pages and state: How do they learn the French language and what do they do to keep in touch with it? What are their difficulties in French? What are their strong points and weak ones in this language? The sample was not large but nevertheless significant. They were 26 students, 23 female students and 3 male students, aged between 21 and 23 .

While reading their answers, I was surprised that all mentioned a common difficulty and weak point related to verb conjugation. I took this difficulty that students were experiencing very seriously and recorded, through the academic year, the mistakes they had made relating to the above-mentioned difficulty. Surprisingly, I found that all of them made mistakes that can be avoided, particularly with regards to the correct use of verbs. Here are some examples of these errors ${ }^{1}$ :

(J'ai appredu [instead of: j'ai appris], j'ai arrivé [instead of: je suis arrivé(e)], pour comprend [instead of: pour comprendre], elle veux comprend [instead of: elle veut comprendre], je peux comprener [instead of: je peux comprendre], vous comprener [instead of: vous comprenez], je memoriser [instead of: je mémorise], il m'aide à comprende [instead of: il m'aide à

\footnotetext{
${ }^{1}$ The correction of the errors focuses only on the conjugation and the structure of the verbs and is not extended to other structural or syntactical errors. In addition, English translation of errors is approximative to give the reader an idea of the type of errors.
} 
comprendre], je n'entendé pas [instead of: je n'entends pas], je faire une exercises [instead of: je fais un exercice], je lire le notes pour plus comprend [instead of: je lis les notes pour mieux comprendre], il étais étudié [instead of: il avait étudié], nous rarement etudier [instead of: nous étudions rarement], je ne écouter pas bien...[instead of: je n'écoute pas bien], je regarder des films ou series sur Netflex. [instead of: je regarde des films et des séries sur Netflix], parfois nous avons écouter le radio [instead of: parfois nous écoutons/ écoutions la radio], j'écrit en anglais et changer en français. [instead of: j'écris en anglais et change en français], j'ai toujours oublier [instead of: j'ai toujours oublié], je comprendre la langue...[instead of: je comprends la langue], tu connaitre les grammaires. [instead of: tu connais la grammaire], j'aime beaucoup apprends [instead of: j'aime beaucoup apprendre], Pour oral, je pense je peux parle français vitement avec mes amis. [instead of: pour l'oral, je pense que je peux facilement parler français avec mes amis], si je ne pas savoir certaine mots, j'ai essayé cherche les mots en dictionnair et j'ai essayer usage les mots souvents. [instead of: si je ne sais / connais pas certains mots, j'essaye de chercher dans le dictionnaire et j'essaye usager (d'utiliser) ces mots souvent], je peux parle français bien, je ne peux pas écrire complexe phrases en français. [instead of: je peux parler bien le français, mais je ne peux pas écrire des phrases complexes en français], j'ai apprendre le français. [instead of: J'ai appris le français], elle aime ecoute de la musique [instead of : elle aime écouter de la musique], on $a$ telecharger éducation apps [instead of : on a téléchargé des applications d'éducation], j'ai apprend écrire [instead of: J'ai appris à écrire.], je besoin pratique [instead of: j'ai besoin de pratiquer], je practiquer moins le français. [instead of: je pratique moins le français], je suis peur [instead of: j'ai peur], pour répond [instead of : pour répondre], je moins lire...[instead of : je lis moins], j'apprend le cours en écouter de la musique française. [instead of: j'apprends le cours en écoutant de la musique française], j'avais toujours demander mon prof... [instead of: j'avais toujours demandé à mon prof...], nous écouter la musique francaise et lire les paroles [instead of : nous écoutons de la musique française et lisons les paroles], je jouer les jeux videos [instead of: je joue aux jeux vidéo], j'ai commencée étudie. [instead of: j'ai commencé à étudier], si j'écoute quelqu'un parle ...[instead of: si j'écoute/entends quelqu'un parler...], j'ai peux lire et comprend facilement, mais j'ai peux ecrire un peu...[instead of: je peux lire et comprendre facilement, mais je peux écrire un peu], je peux memorisez et comprend les textes en français. [instead of: je peux mémoriser et comprendre des textes en français], j'ai lire beaucoup plus et je cherche en ligne. [instead of: je lis beaucoup et cherche en ligne.], Je peux lire, ecrit, écouter...[instead of: je peux lire, écrire, écouter...], Je regarder le video avec mes amis [instead of: je regarde la vidéo avec mes amis.]).

A closer look at the above listed errors will allow us to note that they revolve around the following categories:

- Confusion between infinitive and conjugated verbs (e.g., je mémoriser/mémorise, pour comprend / comprendre).

- Confusion between infinitive verbs and their past participle forms (e.g., nous avons écouter/ écouté).

- Confusion between different past participle forms (e.g., j'ai apprendu/appris, j'ai entendé/entendu).

- Confusion regarding the use of auxiliary verbs (e.g., j'ai arrivé/ suis arrivé, il était étudié/ avait étudié).

- Confusion between verb tenses (e.g., demain, je présenter/présenterai mon exposé, je n'entends pas/ je n'ai pas entendu). 
- Confusion between the conjugated verb endings (e.g., nous étudier/étudions, j'écrit/écris, apprendu/appris, compren/ comprends).

It is noticeable that the confusion between infinitive and conjugated verbs has the lion's share. All other errors are also cut and dry, they indicate clearly the degree of influence of Malay verbal system on the use of different French verbal forms. But the situation here does not allow us to apply the Sherlock Holmes method of observation and deduction when he said in the 'Scandal in Bohemia':

The man who wrote the note is a German. Do you note the peculiar construction of the sentence -'This account of you we have from all quarters received?'- A Frenchman or Russian could not have written that. It is the German who is so uncourteous to his verbs (Doyle, 1888, p. 165)

We are conscious that learners' errors in foreign language constitute a multifaceted and therefore multidisciplinary domain (Mestre, 2011). However, in our case of study we will deal with these kinds of errors only from a linguistic and cognitive standpoint. Thus, to avoid any premature analysis and conclusions, I asked my students, from time to time, to fill in conjugation tables of selected verbs from the above mentioned sentences (e.g, mémoriser 'to memorize', lire 'to read', comprendre 'to understand'). Sometimes, I added very rare verbs (e.g, malaiser 'to feel bad') or verbs with no meaning in French (e.g, mire, tomprendre). The main objective of this exercise was to find out whether there is a difference, in the mind of Malaysian learners, between mechanical learning of verb conjugations in French and reasoning learning which allows them to use verbs in real communicative situations requiring thought and opinion. It also aimed to check their ability to supply a verb with correct endings without necessarily knowing what the verb means.

These latter exercises led us to draw the following observations:

- The percentage of errors decreased.

- The same errors were repeated at a high frequency, thus confirming the confusion between verbs' tenses and aspects. (je lis instead of j'ai lu ; j'ai comprend instead of j'ai compris ; je mémorisé instead of je mémorise, etc.)

- Making the same mistakes of conjugation of either the meaningful verbs or the meaningless verbs of the same group. (J'ai liré; j'ai miré instead of j'ai lu; j'ai mu).

It seems fairly obvious that the degree of difficulty is directly proportional to the number of changes performed on the sentence. In other words, in the latter exercises the conjugations of verbs required only one change or two, but to form sentences the learners were invited to use the verbs in complex structures in a kind of a manipulation which frequently required more transformations and correlations between the elements of the sentences. On the whole, however, the percentage of errors is relatively high when one considers the level of the learners and the difficulties of the task.

\section{Sources of Difficulties and Errors}

To understand more clearly the source of such conflict between the two verbal systems, we will need first to explain the inflectional differences between the verbs in French and in Malay. Grevisse and Goose tell us in the "Bon Usage" (2004) that the French verb is a word that conjugates and takes various forms according to the mode, the tense, the voice, the person, the number and sometimes according to the gender. So if a Malaysian learner wants to use 
the French verb "comprendre / to understand", to refer to his understanding, he will need to use one of the following forms according to the context (je comprends, j'ai compris, je comprenais, j'avais compris, je compris, j'eus compris, je comprendrai, j'aurai compris, je comprendrais, j'aurais compris, que je comprenne, que j'aie compris, que je comprisse, que j'eusse compris, avoir compris, comprenant, ayant compris, en comprenant, en ayant compris). However, he has only one form in his mother tongue (Saya faham) and (difahami) to say (c'est compris / Understood). Here we could borrow the image used by Grevisse and Goose (2004) and consider the French verb as a cinematographic movie and its Malay counterpart as a photograph.

In fact, the French verb informs us through its root and its infinitive form about the action to perform. The conjugated verb informs us about the person and the number of persons who perform the action and when the action is performed. The Malay verb lacks this information.

\section{Person and Number}

If the same learner wants to use the verb (comprendre / to understand) with different subjects/agents, he will need to consider how to make modifications and change the endings of the French verb which varies in person and in number according to the statute of the subject (first, second or third person) and according to its number (singular or plural) (Je comprends / I understand, tu comprends/you understand, il/elle/on comprend/he/she/it understands, nous comprenons/ we understand, vous comprenez/ you "plural" understand, ils /elles comprennent/ they understand). In his mother tongue, on the other hand, he will keep the same form with all different subjects (saya/ I, anda/you, dia/ he or she, kami/ we, anda/ you "plural", mereka/ they, faham/ understand). In Malay grammar, there is no subject-verb agreement rule that requires inflections based on the number of the subject (Maros; Hua and Khazriyati, 2007).

\section{Inflections of Tense and Aspect ${ }^{2}$}

In French the verb expresses the tense via a set of inflections which indicate the time of the action related to the moment of speaking, while the verb in Malay does not have this property and the tense is expressed by auxiliaries (adverbs, expressions of time) which precede the verb in case the time of action is not sufficiently evident through the context (Shehadeh, 2013). The following table will give us a clear idea about the ways expressing the tense of the action in both languages ${ }^{3}$.

\footnotetext{
${ }^{2}$ The aspect in this study is limited to verb conjugation as a marker of aspect in French.

${ }^{3}$ We have limited our analysis in this table to the indicative mode of the French verb.
} 
Table 1: Verb tenses in French and their equivalents in Malay

\begin{tabular}{|c|c|c|}
\hline Indicative Tenses & French & Malay \\
\hline $\begin{array}{l}\text { - Présent / Present } \\
\text { (ongoing action + future } \\
\text { action) }\end{array}$ & $\begin{array}{l}\text { L'enseignant arrive à } 9 \mathrm{~h} 00 \mathrm{du} \\
\text { matin. } \\
\text { [The teacher arrives at 9:00 a.m.] }\end{array}$ & $\begin{array}{l}\text { Cikgu tiba pada pukul } \\
9 \text { pagi. }\end{array}$ \\
\hline $\begin{array}{l}\text { - Passé composé / } \\
\text { Compound past (perfective } \\
\text { action) }\end{array}$ & $\begin{array}{l}\text { L'enseignant est arrivé à 9h00 du } \\
\text { matin. } \\
\text { [The teacher arrived at 9:00 a.m.] }\end{array}$ & $\begin{array}{l}\text { Cikgu telah/sudah } \\
\text { tiba pada pukul } 9 \\
\text { pagi. }\end{array}$ \\
\hline $\begin{array}{l}\text { - Imparfait / imperfect } \\
\text { (perfective-frequentative } \\
\text { action in the past) }\end{array}$ & $\begin{array}{l}\text { L'enseignant arrivait à 9h00 du } \\
\text { matin. } \\
\text { [The teacher arrived at 9:00 a.m.] }\end{array}$ & $\begin{array}{l}\text { Cikgu selalu/ sentiasa } \\
\text { tiba pada pukul } 9 \\
\text { pagi. }\end{array}$ \\
\hline $\begin{array}{l}\text { - Plus-que-parfait / Past } \\
\text { perfect (perfective action } \\
\text { happened before another } \\
\text { action in the past) }\end{array}$ & $\begin{array}{l}\text { L'enseignant était arrivé à 9h00 } \\
\text { du matin. } \\
\text { [The teacher had arrived at 9:00 } \\
\text { a.m.] }\end{array}$ & $\begin{array}{l}\text { Cikgu sudah tiba pada } \\
\text { pukul } 9 \text { pagi tadi. }\end{array}$ \\
\hline $\begin{array}{l}\text { - Passé simple / Simple past } \\
\text { (perfective action "literary") }\end{array}$ & $\begin{array}{l}\text { L'enseignant arriva à 9h00 du } \\
\text { matin. } \\
\text { [The teacher arrived at 9:00 a.m.] }\end{array}$ & $\begin{array}{l}\text { Cikgu telah/sudah } \\
\text { tiba pada pukul } 9 \\
\text { pagi. }\end{array}$ \\
\hline $\begin{array}{l}\text { - Passé intérieur / Past } \\
\text { anterior (perfective action } \\
\text { « literary ») }\end{array}$ & $\begin{array}{l}\text { L'enseignant fut arrivé à 9h00 du } \\
\text { matin. } \\
\text { [The teacher arrived at 9:00 a.m.] }\end{array}$ & $\begin{array}{l}\text { Cikgu telah/sudah } \\
\text { tiba pada pukul } 9 \\
\text { pagi. }\end{array}$ \\
\hline $\begin{array}{l}\text { - Futur simple / Simple future } \\
\text { (action in the future) }\end{array}$ & $\begin{array}{l}\text { L'enseignant arrivera à } 9 \mathrm{~h} 00 \mathrm{du} \\
\text { matin. } \\
\text { [The teacher will arrive at 9:00 } \\
\text { a.m.] }\end{array}$ & $\begin{array}{l}\text { Cikgu akan/bakal tiba } \\
\text { pada pukul } 9 \text { pagi. }\end{array}$ \\
\hline $\begin{array}{l}\text { - Futur proche / Near future. } \\
\text { (Action in the near future) }\end{array}$ & $\begin{array}{l}\text { L'enseignant va arriver à } 9 \mathrm{~h} 00 \mathrm{du} \\
\text { matin. } \\
\text { [The teacher will arrive at 9:00 } \\
\text { a.m.] }\end{array}$ & $\begin{array}{l}\text { Cikgu akan/bakal tiba } \\
\text { pada pukul } 9 \text { pagi } \\
\text { nanti. }\end{array}$ \\
\hline $\begin{array}{l}\text { - Futur intérieur / Future } \\
\text { perfect (Imperfective action } \\
\text { in the future) }\end{array}$ & $\begin{array}{l}\text { L'enseignant sera arrivé à } 9 \mathrm{~h} 00 \\
\text { du matin. } \\
\text { [The teacher will be arriving at } \\
\text { 9:00 a.m.] }\end{array}$ & $\begin{array}{l}\text { Cikgu akan tiba pada } \\
\text { pukul } 9 \text { pagi kelak. }\end{array}$ \\
\hline
\end{tabular}

The above table enables us to note that the French verb (arriver / to come) is shaped and conjugated according to the tense and aspect of the action. In other words, it takes its form according to the perfective, ongoing or imperfective aspect of the action in (the past, the present, the future), whereas its equivalent verb in Malay (tiba) keeps the same form in all times, and the idea of the tense and aspect of the action is expressed by adverbs (telah, sudah / already) for the perfective actions in the past, (selalu, sentiasa / always, constantly) for the continual or habitual actions, and (akan, will) to situate the action in the future. Reduplication in the construction of Malay verbs is also considered as an aspect marker:

It is evinced that verbal reduplication is an aspect marker in Malay. This type of morphology is used to signal progressivity in Malay. The particular morphology of Malay aspect manifests prototypically either by a basic verb stem to denote perfectively, or a reduplicated verb to encode Imperceptivity. (Sew, 2016, p. 45) 


\section{Spoken Inflectional vs Written Inflectional Morphology}

We have seen that French verbs are conjugated and take various forms according to the mode, the tense, the voice, the person, the number and sometimes according to the gender. However, written inflectional morphology does not follow literally the spoken one, as French language tends to pass over the pronunciation of almost all final consonants of the words. If we take the verb (parler / to speak) for example, it will take five forms for the indicative present (parle, parles, parlons, parlez, parlent), while in spoken language it will have only three (parle, parles, parlent $=\backslash$ parl $\backslash$; parlons $=\backslash$ parlõ $\backslash$ and parlez $=\backslash$ parle $\backslash$ ). On top of that, the pronunciation of some forms of different modes is the same, which makes the situation more complicated for the Malaysian learners of French, [(parler (infinitive), parlé (past participle) and parlez (indicative present of second person in plural) $=\backslash$ parle $\backslash$ as all of these three forms have the same pronunciation. Unlike French, Malay language does not pass over the pronunciation of consonants in the end of the words.

So, the huge gap between the two verbal systems and the lack of verb morphology in Malay, lead to huge difficulties in realizing and interpreting agreement, tense and aspect inflectional morphology and consequently to a confusion between the two verbal systems.

\section{A way to Avoid this Interference}

Before approaching this point, we must recognize that French verbs represent a major difficulty in learning either in spoken or in written, in reception or in production (David and Renvoisé, 2010). This means that the right learning process requires time, patience and continuity. Malaysian learners of French are aware of the overwhelming number of parameters that must be controlled to produce sentences with correct forms of verb in French. They sometimes lack the knowhow, but, more importantly, fail to understand why. The majority of these learners are fluent in English, but this added value is not very helpful, as English verb conjugation is too easy and most verbs in present tense have only two forms, and one of them the -s form - is not frequently used in English Malay (Maros et al., 2007). However, we could use the English as a mean to show them that languages differ from each other and that the form infinitive of the verb cannot perform the same functions in all languages as is the case in Malay.

Furthermore, most French teachers teach verb conjugations in a mechanical way through conjugation tables that students are expected to memorize. In other words, they jump to the 'how' without enough focus on the concept of conjugation and its grammatical functions.

To avoid the interference between the two verbal systems or to minimize it, Malaysian learners of French need to fully comprehend the following points:

- The differences between analytic languages such Malay language and synthetic languages such French language. Knowing the differences between these two types of languages will make it easier for Malaysian learners of French to understand that French verbs are shaped differently and consequently they differ in conferring the meaning.

- The notion of the morpheme and the differences between free morphemes and bound morphemes. Stressing that bound morphemes in synthetic languages have syntactically and semantically the same importance as free morphemes in analytic languages.

- Reinforcement of their grammatical understanding through deductive and inductive learning.

- Reinforcement of the explicit knowledge of French verb versus the inhibiting of implicit knowledge of Malay verbs through inductive and deductive exercises and learning until the 
transformation of explicit knowledge of French verbs in the mind of learners becomes implicit knowledge or almost implicit.

The last point is, in our opinion, the cornerstone that can actually contribute to avoid or to minimize the interference between French and Malay verbal systems. Schmidt (1994) argues that explicit knowledge is the result of a learning with awareness (perception, noticing, understanding). Explicit knowledge turns into implicit knowledge once the $L 2$ learner can use it automatically without hesitation, as the native or near-native speakers do. As for the open question of Van Patten (1994) "can explicit knowledge become implicit knowledge"? Hulstijn and De Graaff (1994) pointed out that there is no consensus among specialists of foreign language learning and cognitive linguistics. Therefore, we could refer to three different positions:

- Some theorists, including Anderson (1982), believe that learned explicit knowledge in $\mathrm{L} 2$ can be transformed into acquired implicit knowledge through practice.

- Some others refuse the idea that explicit knowledge became implicit knowledge. Krashen (1982) argues that there is an essential difference between the learning of explicit knowledge and the acquisition of implicit knowledge, and that implicit knowledge can only be acquired by receiving a large amount of comprehensible 'input' as in mother tongue acquisition.

- There are those who adopt a third position, which represents a middle opinion, like Terrell (1991), Ellis (1994) and Dekeyser (1994) who recognize that implicit knowledge acquisition may be easier for certain structures than for others, especially for morphology.

We strongly think that in the case of French verbs, explicit knowledge could become implicit knowledge through time and continual practice. The figure bellow summarizes a way to acquire implicit or near implicit knowledge which allows French learners to use verbal inflections automatically.

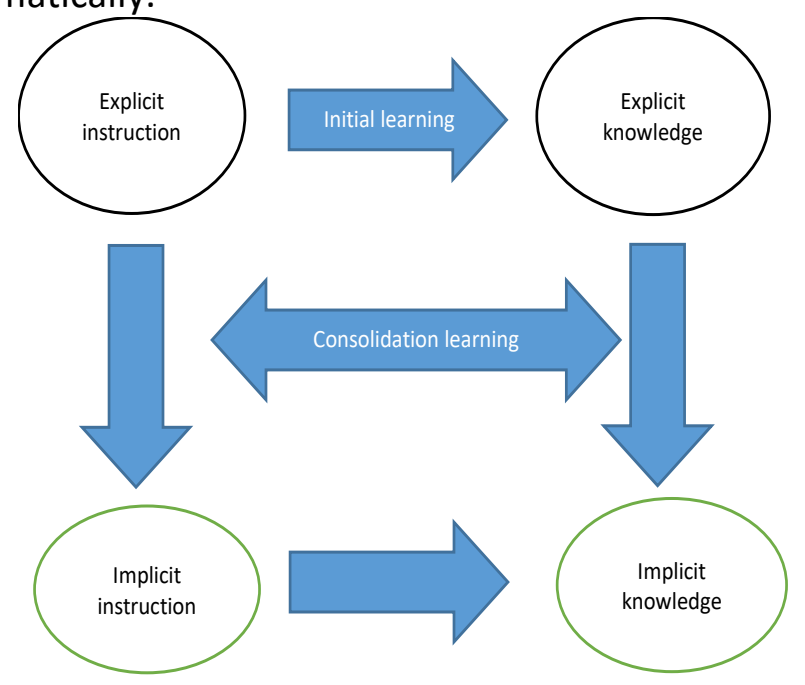

Figure (1)

\section{Conclusion}

Interference between L1 and L2 is commonplace for almost all foreign language learners. It is inevitable and occurs between all languages to varying degrees. This interference could be positive in the case of rapprochement between $L 1$ and $L 2$, but in the case of differences, its effects could be negative according to the degree of spacing. Between Malay and French, the gap is significant, not only in terms of grammatical systems in both languages, but in the role 
and the place of the grammar in each language. While the verb in French plays a pivotal role and is considered syntactically and semantically as the main nucleus of the sentence, the verb in Malay is mainly limited to the expression of the action. However, regarding the subject of this study, which is related to the conflict between French and Malay verbs and the difficulties faced by Malaysian learners of French, we have tried the above-mentioned strategy with our Malaysian learners and the results have been encouraging. Most of them became more aware of the differences between the two verbal systems and, consequently, their errors decreased significantly. So, this study leads us to several conclusions:

- The correct use of French verbs is not beyond the abilities and understanding of Malaysian learners, as argued in the approach of Representational Deficit Hypothesis.

- Performance of learners is dependent largely on the input (Plunkett, 2016). If any learner properly understands the notion of conjugation, its historical and linguistic foundations and the difference between analytic and synthetic languages, he could, through intense practice, perform in French with the minimum of errors. Arabic-speaking learners of French, just to take as an example ${ }^{4}$, have less difficulties with verbs than Malaysian learners of French. In Arabic, the conjugations are more complex, and the verb tends to be stressed in the beginning and in the end. Arabic verbs are conjugated according to the person, the number and the gender of the subject.

- Individual factors and self-motivation play a major role in foreign languages learning. Highly motivated and hardworking learners who persevere in the face of difficulties achieve a very high performance in foreign languages. It is the case of highly motivated and hardworking Malaysian learners of French.

This study is not an intent to form a new approach or theory, but rather a modest effort proposing that the interference of mother tongue, in the case of Malaysian learners of French, could be reduced to a greater level. This study will be significant to improve the French language teaching curricula in countries where analytic languages are spoken. It will also help the French language teachers to understand the extent of languages interference and to know how to overcome the difficulties that learners face to assimilate the importance and the mechanism of French verb and its conjugations. In addition, this study will enhance the abilities of the French language learners to overcome the difficulties resulting from the differences between linguistic systems and to reduce the errors that often affect the communication context.

\section{References}

Abdullah, M. N. A. (2013). Etude comparative des structures et des systèmes verbaux du Français et du Malais. (Doctoral dissertation, Université de Franche-Comté, France). Retrieved from : https://tel.archives-ouvertes.fr/tel-01299798/document

Ali, A. S. (2013). The verbal system of Malay and Arabic: Contrastive analysis. International Journal of Business and Social Science, 4(1), 21-37.

Anderson, J. R. (1982). Acquisition of cognitive skill. Psychological Review, 8, 369-406.

Debyser, F. (1970). La linguistique contrastive et les interférences. Langue Française, 8, 3161.

\footnotetext{
${ }^{4}$ We asked the third-year Yemeni students of French at Taiz University (control group) to do the same exercises that Malaysian students did. It can be, obviously, established that their mistakes regarding the verb conjugations were very few compared to their Malaysian counterparts.
} 
Dekeyser, R. M. (1994). How implicit can adult second language learning be? In J. H. Hulstijn \& R. Schmidt (eds.), Consciousness in second language learning. Aila Review, 11, 83-96.

Doyle, A. C. (1888). The Complete Sherlock Holmes. Doubleday / Penguin Books.

Ellis, N. C. (1994). Psychological perspective on the role of conscious processes in vocabulary acquisition. In J. H. Hulstijn \& R. Schmidt (eds.), Consciousness in second language learning. Aila Review, 11, 37-56.

Esteve, J. (2017). Influence translinguistique dans l'apprentissage en français en Malaisie. (Doctoral dissertation, Université Sorbonne, Paris, France). Retrieved from

Ezeodili, S. (2019). Interférence linguistique dans la production écrite des apprenants du Français Langue Etrangère-Cas des Etudiants de Nnamdi Azikiwe University, Awka. International Journal of Arts and Humanities (IJAH), 8(3), 51-60.

Goad, H., \& White L. (2006). Ultimate attainment in interlanguage grammars: A prosodic approach. Second Language Research, 22(3), 243-268.

Goosse, A., \& Grevisse, M. (2004) Le Bon Usage, 13 " "edn.". Bruxelles : DeBoeck \& Duculot.

Hanafi, A. (2014). The second language influence on foreign language learners' errors: The case of the French language for Algerian students learning English as a foreign language. European Scientific Journal, 2, 30-38.

Hassan, A. (1974). Morphology of Malay. Kuala Lumpur: Dewan Bahasa Pustaka Kementerian Pelajaran Malaysia.

Hawkins, R., \& Chan, C. (1997). The partial availability of universal grammar in second language acquisition: The 'failed functional features hypothesis'. Second Language Research, 13, 187-226.

Hawkins, R. (2000). Persistent selective fossilisation in second language acquisition and the optimal design of the language faculty. Essex Research Reports in Linguistics, 34, 75-90.

Hawkins, R. (2003). Representational deficit theories of adult SLA: Evidence, counterevidence and implications. Plenary paper presented at EUROSLA. Edinburgh.

Hawkins, R. (2004). The Contribution of the theory of universal grammar to our understanding of the acquisition of French as a second language. French Language Studies, 14, 233255. Cambridge University Press.

https://pdfs.semanticscholar.org/3ae6/70521c789b87ffd6dbd4d45b7376d1773899.p df

Hulstijn, J. H., \& De Graaff, R. (1994). Under what conditions does explicit knowledge of a second language facilitate the acquisition of implicit knowledge? In J. H. Hulstijn \& R. Schmidt (eds.), Consciousness in second language learning. Aila Review, 11, 97-112.

Hulstijn, J. H. (2005). Theoretical and empirical issues in the study of implicit and explicit second language Learning. Studies in Second Language Acquisition, 27(2), 129-140.

Krashen, S. D. (1981). Second language acquisition and second language learning. California: University of Southern California, Pergamon Press Inc.

Lekova, B. (1999). Language interference and methods of its overcoming in foreign language: Exploratory case studies of native language interference with target language usage. International Education Journal, 1(1), 22-31.

Liaw, Y. F. (1996). Standard Malay Made Simple. Times Editions Ptd. Ltd.

Maros, M., Hua, T. K., \& Khazriyati, S. (2007). Interference in learning English: Grammatical errors in English essay writing among rural Malay secondary school students in Malaysia. e-BANGI, 2(2), 1-15. 
Mestre, E. M. (2011). Error in the learning and teaching of English as a second language at higher education level. (Doctoral dissertation, Universitat Politècnica De València, Spain). Retrieved from : https://riunet.upv.es/handle/10251/11277

Munkhtsetseg, N. (2017). On the Mongolian students' difficulties in acquiring English relative clauses, due to syntactic structure difference. In E. Piechurska-Kuciel, E. SzymanskaCzaplak, M. Szyszka (Eds.). At the crossroads: challenges of Foreign Language Learning. Second language learning and teaching (pp. 53-74). Springer, Cham.

Ojo, W. O. T. (2014). Interférence linguistique chez les Françisants Anglophones: Le cas du présent de l'indicatif. International Journal of English Language and Linguistics Research, 2(1), 31-38.

Olubunmi, A. O. (2014). Solutions aux problèmes de l'interférence linguistique chez l'apprenant yorubaphone de la langue française au Nigeria. Journal of Arts and Humanities (JAH), 3(5), 51-58.

Patten, B. V. (1994). Evaluating the role of consciousness in second language acquisition: Terms, linguistic features and research methodology. In J. H. Hulstijn \& R. Schmidt (Eds.), Consciousness in second language learning. Aila Review, 11, 27-36.

Plunkett, B. (2016). Microparametric variation and the acquisition of quantitative de in French. In P. Guijarro-Fuentes, M. Juan-Garau \& P. Larrñaga (Eds.), acquisition of romance languages (pp. 65-90). Berlin: De Gruyter Mouton.

Schmidt, R. (1994). Deconstructing consciousness in search of useful definition for applied linguistics. In J. H. Hulstijn \& R. Schmidt (Eds.), Consciousness in second language learning. Aila Review, 11, 11-26.

Sew, J. W. (2016). Aspect in Malay verbs: Realigning time and volition to Malay events. Language Studies, 5(1), 44-63.

Tavakoli, M., Ghadiri, M., \& Zabihi, R. (2014). Direct versus translated writing: The effect of translation on learners' second language writing ability. GEMA Online ${ }^{\circledR}$ Journal of Language Studies, 14(2), 61-74.

Terrell, T. (1991). The role of grammar instruction in a communicative approach. The Modern Language Journal, 75, 52-63.

Vasquez, E., M. (2007). Problems in verb conjugation in Spanish among Malaysian Chinese students: A case study. Journal of Modern Languages, 17(1), 109-128.

Wee, R., Sim, J., \& Jusoff, K. (2010). Verb-form errors in EAP writing. Educational Research and Review, 5(1), 16-23.

Yuko, F. (2017). Reduplication in standard Malay and Japanese. Journal of Modern Languages, 13(1), 65-92. 